\title{
A mouse model of recrudescence of Toxoplasma gondii infection
}

\author{
S. NICOLL, S. WRIGHT*, S. W. MALEY*, S. BURNS $\uparrow$ and D. BUXTON* \\ Centre for Tropical Veterinary Medicine, Easter Bush, Roslin, Midlothian EH25 9RG, * Moredun Research \\ Institute, 408 Gilmerton Road, Edinburgh EH17 7JH and +Regional Virus Laboratory, City Hospital, Greenbank \\ Drive, Edinburgh EH9 5SB
}

\begin{abstract}
Dexamethasone was given to mice infected with Toxoplasma gondii to provide a model of recrudescence of infection in immunocompromised patients and to permit investigation of the interaction between parasite and host.
\end{abstract}

\section{Introduction}

Toxoplasma gondii affects c. 500 million people worldwide [1]. Although it causes a subclinical infection in most individuals, reactivation (or recrudescence) of tissue cysts is an increasing problem in immunosuppressed patients. Clinical toxoplasmosis occurs in 33\% of AIDS patients with evidence of past toxoplasma infection [2] with the development of encephalitis, chorioretinitis and lymphadenopathy. The polymerase chain reaction (PCR) has been used to detect $T$. gondii DNA in peripheral blood samples from sheep [3]. The technique has also been used to detect the parasite in tissue from AIDS patients before clinical manifestations, suggesting that parasitaemia occurs during reactivation, although it may be transient [4].

The aim of this study was to develop a mouse model of $T$. gondii recrudescence. Previous studies have used animals, including athymic (nude) and SCID mice, to investigate interactions between parasite and host during acute infection [5-9]. However, both nude and SCID mice are difficult to work with because of their severely impaired immune systems and the requirement for them to be kept in sterile conditions to prevent opportunist infections. Dexamethasone was administered to clinically normal mice in a study of Pneumocystis carinii [10] and this technique was applied to mice persistently infected with $T$. gondii with a view to inducing recrudescence of infection.

\section{Materials and methods}

\section{Animals}

A pool of 60 chronically infected Porton mice (30 females and 30 males) was established by intraper-

Received 9 Apr. 1996; revised version accepted 13 Aug. 1996.

Corresponding author: Dr S. Nicoll. itoneal inoculation of each with $30 \mathrm{~T}$. gondii tissue cysts of the M3 isolate [11]. A further 40 Porton mice (20 females and 20 males) were kept as uninfected controls. Groups of mice were caged separately and fed with an approved standard ration. Six weeks after infection, two groups of infected mice (groups 1 and 2) were given dexamethasone 8 and $4 \mathrm{mg} / \mathrm{L}$, respectively, in drinking water, and 20 infected mice (group 3) received untreated water. Two uninfected control groups were given dexamethasone $8 \mathrm{mg} / \mathrm{L}$ (group 4) or untreated water (group 5). Treated and untreated water was changed every second day. All groups receiving dexamethasone also received oxytetracyline $1 \mathrm{mg} / \mathrm{L}$ in drinking water for the duration of the study to reduce the risk of contracting other opportunist infections. Blood samples were collected from all groups by tail bleeding before treatment commenced, and weekly thereafter. Mice were monitored daily over 8 weeks for clinical signs of toxoplasmosis; any that showed signs of illness were killed immediately with $\mathrm{CO}_{2}$ gas and samples of brain, blood and heart were taken for analysis. At the end of the 8-week study period all remaining mice were killed and examined in the same way.

\section{Pathology}

The brains were removed from all mice post mortem with stringent aseptic precautions to avoid crosscontamination. Half the brain was placed in a sterile Microfuge tube and stored at $-20^{\circ} \mathrm{C}$ until required for PCR analysis. The other half was placed in formol saline $10 \%$ for 7 days. Each was then sectioned coronally and four blocks were dehydrated through graded alcohols and toluene before embedding in paraffin wax. Sections $5 \mu \mathrm{m}$ thick were cut and stained with haematoxylin and eosin (HE) and then examined for lesions. Sections with minimal to mild histopathological lesions were scored + , and those with moderate to severe change were scored ++ . 


\section{PCR analysis and serology}

Samples of blood taken weekly, and blood, brain and heart obtained post mortem were examined by PCR for the presence of the Bl gene of $T$. gondii [12]. Plasma samples collected on day 0 and post mortem were tested for $\lg G$ against $T$. gondii by an ELISA modified for use in mice [13].

\section{Statistical analysis}

The effect of dexamethasone on the morbidity rate and on the presence or absence of the parasite in samples was analysed by Fisher's exact test.

\section{Results}

Signs of illness included a tottering gait coupled with a hunched appearance and evidence of emaciation and dehydration. Eight of $20(40 \%)$ mice given dexamethasone at $8 \mathrm{mg} / \mathrm{L}$ developed clinical signs and were killed, compared with two $(10 \%)$ of 20 given $4 \mathrm{mg} / \mathrm{L}$ $(p=0.049)$, and none of the control groups $(p=$ 0.0027 ). Uninfected control mice did not show signs of toxoplasmosis, but one uninfected mouse given dexamethasone died suddenly. Parasite DNA was detected by PCR in nine samples of brain, six samples of heart and three samples of blood (no sample was obtained from one mouse) collected from the 10 mice that developed clinical signs of toxoplasmosis. All samples from infected mice that did not receive dexamethasone (group 3) and uninfected controls (group 4 and 5) gave negative results.

Blood samples collected at weekly intervals were positive by the PCR in $49(38.9 \%)$ of 126 samples from group 1 (dexamethasone $8 \mathrm{mg} / \mathrm{L}$ ), $32(23.4 \%$ ) of 137 samples from group 2 (dexamethasone $4 \mathrm{mg} / \mathrm{L}$ ), and $12(8.6 \%)$ of 140 samples in group 3 (no dexamethasone). The results of group 1 versus group $2(\mathrm{p}=0.0064)$, group 1 versus group $3(\mathrm{p}<0.0001)$ and group 2 versus group $3(\mathrm{p}=0.008)$ were highly significant.

Blood samples taken from survivors at the end of the experiment were positive by the PCR in four $(33.3 \%)$ of 12 mice from group 1 , five $(27.7 \%)$ of 18 from group 2, and three $(15 \%)$ of 20 from group 3 (differences were not significant). All 12 samples of brain from mice given dexamethasone at $8 \mathrm{mg} / \mathrm{L}$ (group 1) were positive, compared with $16(88.8 \%)$ of 18 that received dexamethasone at $4 \mathrm{mg} / \mathrm{L}$ (group 2 ), and $15(75 \%)$ of 20 that received no dexamethasone (group 3). These differences were not significant. Similarly, all 12 samples of heart were positive in group $1,15(83.3 \%)$ of 18 in group 2 , and nine $(45 \%)$ of 20 in group 3 (significance between groups 1 and $3 ; \mathrm{p}=0.0006)$.

\section{Pathology}

Examination of brain showed three patterns of neuropathological lesions; (i) focal necrosis that occurred in the thalamus or cerebral cortex or both; (ii) foci of gliosis that ranged from small to large clusters of cells; (iii) lymphoid inflammation with perivascular cuffing by lymphoid cells as well as meningeal accumulations of similar cells (Fig. 1). The results are summarised in Table 1.

Necrosis was observed in two mice with no evidence of recrudescence (group 1) and in five infected mice with clinical signs of infection; all of them had been given dexamethasone. Gliosis was observed in 14 $(70 \%)$ of 20 samples from group 1, $13(65 \%)$ of 20 samples from group 2, and $15(75 \%)$ of 20 samples from group 3, and was more frequently observed in clinically affected than in clinically normal animals. The incidence of lymphoid inflammation was similar in groups 1, 2 and $3(85 \%, 90 \%$ and $100 \%$, respectively) but tended to be more severe in group 3 .

T. gondii tissue cysts were observed in brains of infected mice $(40 \%, 30 \%$ and $35 \%$ of mice,
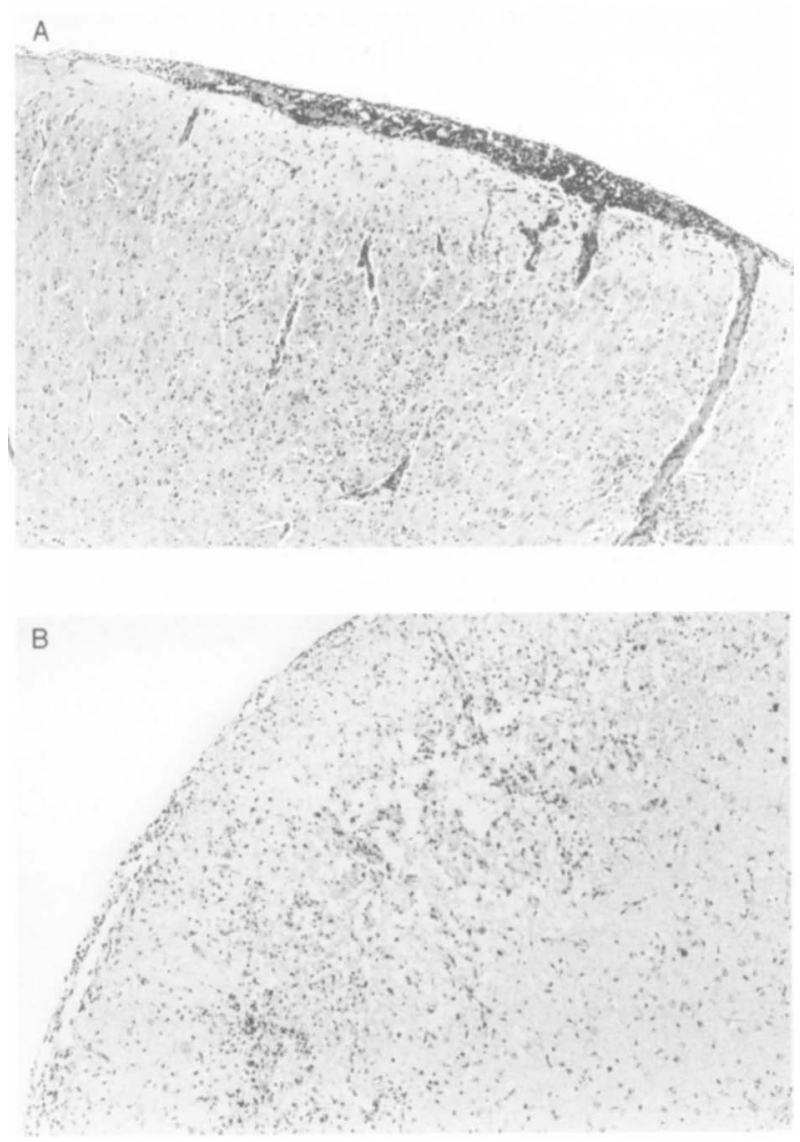

Fig. 1. (A) Lymphoid meningitis and an associated glial response in the cerebral cortex of a mouse infected with $T$. gondii and treated with dexamethasone $(4 \mathrm{mg} / \mathrm{L}$ in drinking water) $(\mathrm{HE} \times 56)$. (B) Acute necrosis in the cerebral cortex of a mouse infected with $T$. gondii and treated with dexamethasone $(4 \mathrm{mg} / \mathrm{L}$ in drinking water $)$ $(\mathrm{HE} \times 56)$. 
Table 1. Results of pathological examination of brain sections tested

\begin{tabular}{|c|c|c|c|c|c|c|c|}
\hline \multirow[b]{3}{*}{ Experimental group } & \multirow{3}{*}{$\begin{array}{l}\text { Number } \\
\text { of mice } \\
\text { examined }\end{array}$} & \multicolumn{6}{|c|}{ Number of mice with } \\
\hline & & \multicolumn{2}{|c|}{ Necrosis } & \multicolumn{2}{|c|}{ Gliosis } & \multicolumn{2}{|c|}{ Lymphoid inflammation } \\
\hline & & + & ++ & + & ++ & + & ++ \\
\hline Infected, dexamethasone $8 \mathrm{mg} / \mathrm{L}$ (group 1) & $20(8)$ & $5(3)$ & $1(1)$ & $12(5)$ & $2(1)$ & $16(7)$ & $1(1)$ \\
\hline Infected, dexamethasone $4 \mathrm{mg} / \mathrm{L}$ (group 2) & $20(2)$ & $0(0)$ & $1(1)$ & $11(1)$ & $2(1)$ & $15(1)$ & $3(1)$ \\
\hline Infected, no dexamethasone (group 3) & $20(0)$ & () & 0 & $13(0)$ & $2(0)$ & $14(0)$ & $6(0)$ \\
\hline Uninfected, dexamethasone $8 \mathrm{mg} / \mathrm{L}$ (group 4) & 20 & 0 & 0 & 0 & 0 & 0 & 0 \\
\hline Uninfected, no dexamethasone (group 5) & 20 & 0 & 0 & 0 & 0 & 0 & 0 \\
\hline
\end{tabular}

Numbers in parentheses indicate those mice in groups 1,2 and 3 showing clinical signs of illness.

respectively, in groups $1-3$ ), but not in uninfected control mice. Tissue cysts in groups 1 and 2 seemed to be adjacent to areas of inflammation whereas in group 3 they were generally unassociated with other changes.

\section{Serology}

Blood samples obtained on day 0 from infected mice were positive by IgG ELISA (OD values: 119.7128.6), whereas those from uninfected mice were negative (OD values $<25$ ). Samples from infected mice remained positive after treatment with dexamethasone, but the mean OD value fell from 121.5 to 99.5 in mice given dexamethasone $8 \mathrm{mg} / \mathrm{L}$.

\section{Discussion}

Dexamethasone has been used successfully to create a mouse model of $P$. carinii infection [10]. In the present study mice persistently infected with $T$. gondii and given dexamethasone exhibited increased morbidity, especially when a high dose of $8 \mathrm{mg} / \mathrm{L}$ was used (group 1), compared with untreated mice (group 3). Treated mice exhibited classic locomotor signs of toxoplasmosis which were not observed in any of the control groups. While there were no differences in the detection of parasite DNA in samples of blood and brain from infected mice, the samples of heart were more frequently positive in those given dexamethasone (groups 1 and 2) than in untreated mice (group 3). Lower levels of $T$. gondii $\operatorname{IgG}$ were found in mice given the higher dose of dexamethasone (group 1), providing further evidence of the immunosuppressive effect of this treatment.

Pathological examination of brain sections revealed two effects of dexamethasone. First, it acted as an immunosuppressant to allow recrudescence of a chronic infection in a number of mice; second, the drug had an anti-inflammatory effect, so that increased intake of dexamethasone resulted in a slight increase in the extent of necrosis. Infected mice given dexamethasone showed a slight reduction in the severity of gliosis and lymphoid inflammation, which appeared to be a result of the anti-inflammatory effects of dexamethasone treatment. However, most mice that developed clinical symptoms of toxoplasmosis developed moderate to severe gliosis and lymphoid inflammation.

Dexamethasone can induce recrudescence of toxoplasmosis in persistently infected mice to mimic the effects observed in the human AIDS population, in which $30-35 \%$ of previously infected individuals develop clinical signs of infection [2]. This model should facilitate investigation of the parasite-host interaction, although account must be taken of the anti-inflammatory effects of the drug.

This work was funded by the Medical Research Council (SPG 9022510). Much of the work was carricd out at the Infectious Diseases Unit, City Hospital, Edinburgh with the assistance of Dr C. S. L. Leen and Dr R. P. Brettle. Statistical analysis was by Linda Williams. S. W., S. M., D. B. and L. W. were supported by the Scottish Office Agriculture Environment and Fisheries Department.

\section{References}

1. Hughes HPA. Toxoplasmosis: the need for improved diagnostic techniques and accurate risk assessment. Curr Top Microbiol Immunol 1985; 120: 105-139.

2. Luft BJ, Remington JS. Toxoplasmic encephalitis in AIDS. Clin Infect Dis 1992; 15: 211-222.

3. Wastling JM, Nicoll S, Buxton D. Comparison of two gene amplification methods for the detection of Toxoplasma gondii in experimentally infected sheep. .J Med Microbiol 1993; 38: $360-365$.

4. Nicoll S, Burns SM, Brettle RP, Leen CSL. A comparison of two methods of gene amplification for the diagnosis of Toxoplasma gondii in AIDS. $J$ Infect (in press).

5. Conley FK, Jenkins KA. Immunohistological study of the anatomic relationship of Toxoplasma antigens to the inflammatory response in the brains of mice chronically infected with Toxoplasma gondii. Infect Immun 1981; 31: 1184-1192.

6. Ferguson DJP, Hutchison WM. The host-parasite relationship of Toxoplasma gondii in the brains of chronically infected mice. Virchows Arch Pathol Anat Histopathol 1987; A411: $39-43$.

7. Lindberg RE, Frenkel JK. Toxoplasmosis in nude mice. J Parasitol 1977; 63: 219-221.

8. Buxton D. Experimental infection of athymic mice with Toxoplasma gondii. J Med Microbiol 1980; 13: 307-311.

9. Johnson LL. SCID mouse models of acute and relapsing chronic Toxoplasma gondii infections. Infect Immun 1992; 60: 3719-3724.

10. Powles MA, McFadden DC, Pittarelli LA, Schmatz DM. Mouse model for Pneumocystis carinii pneumonia that uses natural transmission to initiate infection. Infect Immun 1992; 60: $1397-1400$.

11. Buxton D, Thomson K, Maley S, Wright S, Bos HJ. Vaccination of sheep with a live incomplete strain (S48) of 
Toxoplasma gondii and their immunity to challenge when pregnant. Vet Rec 1991; 129: 89-93.

12. Burg JL, Grover CM, Pouletty P, Boothroyd JC. Direct and sensitive detection of a pathogenic protozoan, Toxoplasma gondii, by polymerase chain reaction. J Clin Microbiol 1989;
27: $1787-1792$.

13. Buxton D, Blewett DA, Trees AJ, McColgan C, Finlayson J Further studies in the use of Monensin in the control of experimental ovine toxoplasmosis. J Comp Pathol 1988; 98: 225-236. 